\title{
PERLINDUNGAN HUKUM BAGI PENCIPTA LAGU PADA MEDIA INTERNET ( Kajian Yuridis Sosiologis)
}

\author{
Alfin Andrey Ryanto, Adi Suliantoro \\ Fakultas Hukum, Universitas Stikubank (UNISBANK) Semarang \\ E-mail : alfinkopleds@gmail.com, adisuliantoro65@gmail.com
}

\begin{abstract}
ABSTRAK
Permasalahan terkait ilegal downloading masih menjadi masalah bagi para pencipta lagu atau musisi di Indonesia. Dalam UUHC dan UU ITE juga telah diatur terkait perlindungan terhadap pelanggaran hak cipta melalui media internet, Pada kenyataanya, pemberlakuan UU tersebut kurang tegas. Berdasarkan penjelasan yang diberikan terhadap uraian diatas, maka penelitian ini diberi judul "Perlindungan Hukum Bagi Pencipta Lagu Pada Media Internet (Kajian Sosiologi Hukum).”

Perumusan masalah penelitian ini adalah bagaimana perlindungan hukum bagi pencipta lagu pada media internet, bagaimana tanggung jawab pihak penyedia jasa Download Mp3 lagu gratis terhadap pelanggaran hak cipta melalui media internet terhadap pencipta lagu, Persepsi masyarakat terkait perlindungan terhadap lagu-lagu yang diedarkan di media internet.

Metode pendekatan yang digunakan dalam penelitian ini adalah yuridis sosiologis. Spesifikasi penelitian dilakukan secara deskriptif analitis. Metode penyajian data dalam penelitian ini dilakukan dengan cara wawancara langsung dengan masyarakat atau mengisi kuisioner di internet. Analisis yang dipergunakan dalam penulisan ini adalah kualitatif.

Hasil penelitian menunjukkan bahwa perlindungan hukum pencipta lagu sudah otomatis dilindungi oleh UUHC, pemerintah juga sudah mengupayakan untuk pemblokiran situs download lagu ilegal tetapi realitanya masyarakat masih banyak mengunduh lagu ilegal pada media internet,Pertanggungjawaban situs penyedia jasa download lagu gratis, dalam perkembangan pelanggaran hak cipta melalui media internet biasanya dibebankan kepada Internet Service Provider (ISP) jika provider menyediakan fasilitas yang memungkinkan terjadinya pelanggaran hak cipta. Penyedia situs justru menjadi sebuah penyimpangan, situs tersebut mengalihkan kedudukannya sebagai situs illegal menjadi situs legal dengan memposisikan diri mereka sebagai situs pencari lagu, penyedia lagu dalam hal tersebut telah bertentangan dengan Undang-undang. Persepsi masyarakat tentang individu yang melakukan download lagu hal yang salah karena melanggar UU Hak Cipta. Masyarakat sadar pelanggaran Hak Cipta, namun menurut fakta di lapangan masyarakat masih mendownload lagu tanpa izin. Perilaku ini dilakukan karena perlindungan lagu oleh Pemerintah kurang kuat. Belum ada sanksi yang tegas untuk penyedia lagu gratis di internet dan pengunduh lagu gratis di internet.
\end{abstract}

\section{Kata Kunci : Perlindungan UUHC,Download Lagu,Penyedia Jasa pada Media Internet}




\begin{abstract}
Problems related to illegal downloading are still a problem for songwriters or musicians in Indonesia. In the UUHC and the ITE Law, it has also been regulated regarding the protection of copyright infringement through the internet media. In fact, the enforcement of this law is less firm. Based on the explanation given to the description above, this research is entitled "Legal Protection for Songwriters on Internet Media (Sociology of Law Studies)."

The formulation of the problem of this research is how the legal protection for songwriters on the internet media, how is the responsibility of the free Mp3 song download service provider against copyright infringement through the internet media for songwriters, public perception regarding the protection of songs circulated on the internet media.

The approach method used in this research is sociological juridical. The research specification was carried out by descriptive analytical. The method of presenting data in this study was carried out by direct interviews with the community or filling out questionnaires on the internet. The analysis used in this paper is qualitative.

The results show that the legal protection of songwriters has been automatically protected by UUHC, the government has also made efforts to block illegal song download sites but in reality people still download illegal songs on the internet, the responsibility of free song download service providers, in the development of copyright infringement through Internet media is usually charged to the Internet Service Provider (ISP) if the provider provides facilities that allow copyright infringement to occur. Site providers have actually become an irregularity, these sites have shifted their position from being an illegal site to a legal site by positioning themselves as a song search site, the song provider in this case has violated the law. Public perception about individuals who download songs are wrong because they violate the Copyright Law. The public is aware of copyright infringement, but according to facts on the ground, people still download songs without permission. This behavior is carried out because the protection of songs by the Government is not strong enough. There are no strict sanctions for providers of free songs on the internet and free song downloaders on the internet.
\end{abstract}

\title{
Keywords: UUHC Protection, Download Songs, Service Providers on Internet Media
}




\section{Pendahuluan}

Kekayaan intelektual merupakan kekayaan atas segala hasil produksi kecerdasan daya pikir seperti teknologi, pengetahuan, seni, sastra, gubahan lagu, karya tulis, karikatur, dan lain-lain yang berguna untuk manusia. Sementara, objek kekayaan intelektual merupakan hasil kerja rasio manusia dengan menggunakan logika yang dituangkan ke dalam suatu karya dan kemudian dirumuskan sebagai intelektualitas, dapat menjadi menjadi suatu gagasan dan ide. Gagasan atau ide yang diambil melalui suatu pemikiran secara rasional tersebut tentu saja tidak semua orang dapat dan mampu melakukannya. Oleh sebab itu suatu gagasan yang bermanfaat bagi praktek kehidupan sehari-sehari bernilai ekonomi, sehingga perlu diberikan suatu perlindungan dalam hal penggunaannya. Hak Cipta memberikan perlindungan terhadap karya-karya cipta di bidang Seni, Sastra dan Ilmu Pengetahuan dan pemberian hak cipta itu didasarkan pada kriteria keaslian sehingga yang penting adalah bahwa ciptaan itu harus benar-benar berasal dari pencipta yang bersangkutan, bukan merupakan jiplakan maupun tiruan karya pihak lain. Dalam Pasal 40 Ayat 1 UndangUndang Hak Cipta telah ditentukan ciptaan apa saja yang dilindungi yang semuanya berada dalam ruang lingkup ciptaan di bidang seni, sastra, dan ilmu pengetahuan, sebagai berikut :

a. Buku, pamflet, susunan perwajahan karya tulis yang diterbitkan, dan semua hasil karya tulis lainnya; b. Ceramah, kuliah, pidato dan ciptaan sejenis lainnya;

c. Alat peraga yang dibuat untuk kepentingan pendidikan dan ilmu pengetahuan;

d. Lagu dan atau musik dengan atau tanpa teks;

e. Drama, drama musikal, tari koreografi, pewayangan, dan pantomim;

f. Karya seni rupa dalam segala bentuk seperti lukisan, gambar, ukiran, kaligrafi, seni pahat, patung, atau kolase;

g. Karya seni terapan;

h. Karya arsitektur;

i. Peta;

j. Karya seni batik atau seni motif lain;

k. Karya fotografi;

1. Potret;

m. Karya seni matografi;

n. Terjemahan, tafsir, saduran, bunga rampai, basis data, adaptasi, aransemen, modifikasi, dan karya lainnya dari hasil transformasi;

o. Terjemahan, adaptasi, aransemen, transformasi, atau modifikasi ekpresi budaya tradisional;

p. Kompilasi ciptaan atau data, baik dalam format yang dapat dibaca dalam program komputer maupun media lainya;

q. Kompilasi ekpresi budaya tradisional selama kompilasi tersebut merupakan karya yang asli;

r. Permainan video; dan 
s. Program Komputer.

Berdasarkan

bentuk pengungkapannya, seni terbagi dalam tiga jenis yaitu seni penglihatan (virtual art), seni pendengaran (audio art) dan seni penglihatan dan pendengaran (audiotory visual art). Untuk seni berdasarkan nilai dan tujuannya dapat dibedakan menjadi dua jenis yaitu seni murni dan seni terapan. Untuk seni musik sendiri dapat dibedakan menjadi dua yaitu seni lagu (seni vokal) dan seni instrumental. Seni lagu merupakan salah satu bagian yang tidak bisa terlepas dari kehidupan kita seharisehari. Pada tingkat kehidupan masyarakat sekarang ini lagu atau musik bukan lagi sekedar sarana hiburan yang akan habis setelah dinikmati tanpa memberikan dampak apapun bagi pencipta maupun penikmatnya. Pada tingkat kehidupan masyarakat sekarang ini lagu atau musik bukan lagi sekedar sarana hiburan yang akan habis setelah dinikmati tanpa memberikan dampak apapun bagi pencipta maupun penikmatnya. Di era media internet sekarang ini, lagu ciptaan Piyu tersebut dapat kita nikmati tanpa repot-repot pergi ke toko kaset untuk membeli. Cukup dengan men-download melalui internet, kita dapat menikmati lagu tersebut tanpa perlu mengeluarkan biaya, oleh karena itu banyak situs penyedia jasa download lagu gratis mengunggah lagu tersebut dengan tujuan untuk dibagi secara gratis, dan untuk kepentingan situs tersebut. Bukan dalam rangka pencipta lagu melakukan pengumuman atas hasil ciptaannya. Beberapa contoh situs penyedia jasa download $M p 3$ gratis yaitu, DownloadMp3Gratis.com, Music-corner.com, MissHacker.com, GudangLagu.com, Metrolagu.com, Spotify.com. Kemudahan yang disajikan oleh situs penyedia jasa Download Mp3 gratis tersebut tidak sebanding lurus dengan keuntungan yang diterima oleh pencipta lagu. Situs penyedia jasa download Mp3 lagu gratis telah melanggar hak pencipta lagu yang dilindungi oleh undangundang, dimana lagu tersebut juga dilindungi oleh hukum secara otomatis, sejak ciptaan itu diwujudkan dalam bentuk nyata. Permasalahan terkait ilegal downloading masih menjadi masalah bagi para pencipta lagu atau musisi di Indonesia. Dalam UUHC dan UU ITE juga telah diatur terkait perlindungan terhadap pelanggaran hak cipta melalui media internet, di antaranya terdapat sejumlah sanksi yang dibebankan kepada pelaku pelanggaran hak cipta baik itu berupa pidana penjara maupun sejumlah denda tertentu. Namun, pada kenyataanya, pemberlakuan UU tersebut tidak dijalankan. Berdasarkan penjelasan yang diberikan terhadap uraian diatas, maka penelitian ini diberi judul "Perlindungan Hukum Bagi Pencipta Lagu Pada Media Internet (Kajian Yuridis Sosiologis)." Berdasarkan uraian dari latar belakang yang telah dikemukakan diatas, maka perumusan masalah yang timbul dalam penelitian adalah sebagai berikut :

1. Bagaimana perlindungan hukum bagi pencipta lagu pada media internet? 
2. Bagaimana tanggung jawab pihak penyedia jasa Download Mp3 lagu gratis terhadap pelanggaran hak cipta melalui media internet terhadap pencipta lagu?

3. Bagaimanakah persepsi masyarakat terkait perlindungan terhadap lagu-lagu yang diedarkan di media internet?

\section{Metode Penelitian}

Penelitian tentang keadaan nyata masyarakat atau lingkungan masyarakat dengan maksud dan tujuan untuk menemukan fakta tentang persepsi masyarakat tentang situs download lagu internet secara gratis tanpa izin dari pencipta lagu ini merupakan suatu penelitian hukum dengan mempergunakan cara pendekatan yuridis sosiologis.

Fokus penelitian menggunakan penelitian yang diskriptif. Penelitian diskriptif maksudnya penelitian ini mempunyai maksud untuk memberikan gambaran secara rinci, sistematis dan menyeluruh mengenai persepsi masyarakat tentang ilegal downloading lagu pada media internet ketika terjadi adanya pelanggaran hak cipta.

Data yang dikumpulkan adalah fakta-fakta yang diperoleh secara langsung di lapangan dengan melakukan wawancara dengan pihak pencipta lagu dan masyarakat yang berkaitan dengan penelitian yang dilakukan serta akan ditinjau pula dengan teori-teori hukum HKI serta pengumpulan data dalam penelitian ini ditunjang dengan perundang-undangan yang berlaku yakni Undang-Undang Nomor 28 Tahun 2014 tentang Hak
Cipta dan Undang-Undang Nomor 11 Tahun 2008 tentang Informasi dan Transaksi Elektronik.

\section{Pembahasan}

\section{Perlindungan Hukum Bagi Pencipta Lagu Pada Media Internet}

Di dalam Undang-Undang Nomor 28 Tahun 2014 tentang Hak Cipta, dikenal azaz perlindungan otomatis (automatical protection), artinya bahwa sebuah karya cipta yang diwujudkan oleh penciptanya, maka sejak saat itu secara otomatis karya cipta tersebut memiliki hak cipta dan mendapat perlindungan secara hukum. Pencipta tersebut membuat karya ciptaan seni musik berupa lagu. Untuk pengamanan pada karya cipta tersebut akan lebih baik seandainya didaftarkan, khususnya apabila pada suatu saat terbentur pada masalah hukum yang berhubungan dengan ciptaanciptaan yang ada. Hak Cipta dalam Pasal 4 merupakan Hak eksklusif yang terdiri dari hak moral dan hak ekonomi. Hak moral adalah hak yang melekat secara abadi pada diri pencipta untuk mengumumkan nama salinan untuk ciptaannya untuk umum,menggunakan nama aslinya atau samaran,mempertahankan haknya dalam hal terjadi distorsi ciptaan, mutilasi ciptaan, modifikasi ciptaan atau hal yang merugikan kehormatan diri. Hak ekonomi adalah hak eksklusif pencipta atau pemegang cipta 
untuk manfaat ekonomi atas ciptaan. Dalam Pasal 9 ayat 2 setiap orang yang melaksanakan hak ekonomi sebagaimana dimaksud wajib mendapatkan izin pencipta atau pemegang hak cipta. Undang-Undang Nomor 28 Tahun 2014 mengenai Hak Cipta telah menyediakan dua sarana hukum, yang dapat dipergunakan sekaligus menindak pelaku pelanggaran terhadap hak cipta, yakni sarana hukum pidana dan hukum perdata. Salah satu objek hak cipta paling sering dilanggar adalah karya seni musik berupa lagu. Penyediaan lagu secara gratis oleh situs penyedia jasa download berupa lagu gratis secara nyata telah melanggar hak cipta dari lagu tersebut, karena lagu tersebut diunggah tanpa persetujuan pencipta atau pemegang hak ciptanya. Penyedia lagu di situs jasa download lagu gratis semestinya menjadi masalah yang mendapat perhatian khusus, karena telah mencakup permaslahan pelanggaran hak cipta oleh situs tersebut. UUHC kurang begitu efektif dengan kurangnya sosialisasi dan banyak musisi atau pencipta lagu asli tidak terlalu ribet dengan pelanggaran Hak Cipta yang dilakukan terhadap situs jasa download lagu. Terhadap perlindungannya disini sama sekali pihak Gudang Lagu tidak memberikan perlindungan hukum sama sekali terhadap pencipta lagu yang berada disitus tersebut. Disinilah kurangnya perlindungan terhadap pencipta lagu karena di situs penyedia jasa download illegal di internet lagu-lagu bisa diedarkan secara gratis sedangkan pencipta mungkin tidak dapat royalti dari situs tersebut. Analisa yuridis sosiologis terhadap perlindungan pencipta lagu merupakan aktivitas gejala-gejala sosial yang terjadi dimasyarakat. Kajian yuridis sosiologis ini sangat melekat pada kehidupan sehari-hari di masyarakat. Penyebab yang mendorong perlindungan hak cipta adalah ini kurangnya pemahaman masyarakat akan pentingnya Undang-Undang tentang Hak Cipta. Apabila pengetahuan hukum saja yang dimiliki oleh masyarakat, hal itu belum memadai, masih diperlukan pemahaman atas hukum yang berlaku. Melalui pemahaman hukum, masyarakat diharapkan memahami tujuan peraturan perundang-undangan serta manfaatnya bagi pihak-pihak yang kehidupannya diatur oleh perundang-undangan dimaksud.

\section{Tanggung Jawab Pihak} Penyedia Jasa Download MP3 Lagu Gratis terhadap Pelanggaran Hak Cipta Melalui Media Internet terhadap Pencipta Lagu

Pertanggungjawaban situs penyedia jasa download lagu gratis, dalam perkembangan pelanggaran hak cipta melalui media internet biasanya dibebankan kepada Internet 
Service Provider (ISP) jika provider menyediakan fasilitas yang memungkinkan terjadinya pelanggaran hak cipta dalam media internet. Namun tidak selamanya provider dapat dimintai pertanggungjawaban terhadap semua pelanggaran hak cipta yang dilakukan oleh user yang $\log$ in ke internet. Sehubungan dengan pelanggaran Hak Cipta yang dilakukan oleh penyedia jasa download lagu di dalam media internet ini mendapat imbasnya. Penyelenggara Jasa Internet (PJI). PJI yaitu menyediakan akses ke intenet kepada user atau masyarakat pengguna intenet. Beberapa jasa layanan tambahan yang diberikan PJI dinilai juga potensi besar turut membantu mengakibatkan terjadinya pelanggaran Hak Cipta. Banyak dari situs penyedia jasa download lagu gratis ilegal yang diminati pertanggung jawaban atas pelanggaran yang dilakukan justru melakukan beberapa spekulasi agar terlihat seperti situs legal. Dikatakan illegal sebab situs tersebut mendasarkan layanannya pada system pnyediaan lagu yang berarti situs ini berperan aktif dalam proses upload lagu. Pelaku pelanggaran hak cipta yang dapat dimintakan pertanggungjawaban hukum adalah pelaku yang secara langsung melakukan pelanggaran hak cipta (direct infringement). Namun dalam hal ini, contohnya pihak GudangLagu.com, mengelak untuk mengakui bahwa situs terdebut adalah illegal.
Pertanggungjawaban situs penyedia jasa download lagu gratis Gudang Lagu dalam hal ini tidak memberikan perlindungan sama sekali terhadap pencipta lagu yang lagunya terdapat disitus tersebut. Dalam perkembangan pelanggaran hak cipta melalui media internet biasanya dibebankan kepada Internet Service Provider (ISP) jika provider menyediakan fasilitas yang memungkinkan terjadinya pelanggaran hak cipta dalam media internet. Namun tidak selamanya provider dapat dimintai pertanggungjawaban terhadap semua pelanggaran hak cipta yang dilakukan oleh user yang log in ke internet. Upaya pemblokiran yang dilakukan pemerintah tidak cukup efektif memberikan efek jera kepada situs-situs illegal yang ada, sehingga muncul situs-situs illegal lain yang juga melakukan pelanggaran hak cipta. Apalagi dengan adanya alasan dengan berbagai informasi dan hak untuk mendapatkan informasi yang sering dijadikan alasan para illegal downloader dan illegal uploader sebagai pembenaran dan pembelaan akan pelanggaran hak cipta yang dilakukan. Oleh karena belum adanya tanggungjawab oleh situs penyedia jas download lagu gratis, pemerintah sudah seharusnya mengatur kebijakan yang lebih mengikat dan efektif untuk menghentikan pelanggaran hak cipta oleh situs-situs tersebut. Analisa kajian yuridis sosiologis terhadap tanggung jawab pihak 
penyedia jasa download lagu ini dianggap masih kurang oleh masyarakat. Karena masyarakat menilai masih dapat situs penyedia jasa download lagu tidak bertanggung jawab akan pentingnya hak dari pencipta lagu. Seperti situs Gudang Lagu dan Stafaband yang sering digunakan oleh masyarakat untuk mendownload lagu tersebut secara gratis tanpa ijin pencipta lagu. Dari perilaku masyarakat yang sering mendowload lagu di situs tersebut, pihak Gudang Lagu dan Stafaband tidak memberikan tanggung jawab terhadap perlindungan pencipta lagu atas lagunya yang terdapat disitus tersebut. Dalam hal ini disebabkan kondisi masyarakat dan memandangi sebuah persoalan tersebut kurangnya pengetahuan dan kepatuhan masyarakat itu terhadap suatu aturan hukum yang dapat melindungi pencipta lagu dari pelanggaran hak cipta. Pengetahuan hukum masyarakat akan dapat diketahui bila diajukan seperangkat pertanyaan mengenai pengetahuan hukum tertentu.

\section{Persepsi Masyarakat Terkait Perlindungan Terhadap Lagu- Lagu yang diedarkan di Media Internet}

Data penelitian tentang persepsi masyarakat terhadap lagu-lagu yang di edarkan di media internet, diperoleh dengan instrument angket melaui kuisioner yang terdiri dari 14 butir pertanyaan. Angket ini terdiri atas
14 butir soal pertanyaan yang dinyatakan valid adalah 11 butir soal, sedangkan yang dinyatakan tidak valid adalah 3 butir soal antara lain soal no.11, 12, dan 14.

Berdasarkan pengumpulan data persepsi masyarakat terkait perlindungan terhadap lagu-lagu yang diedarkan di media internet diukur dengan menggunakan kuesioner dengan skala likert, dengan hasil deskripsi data secara statistic. Dari pengumpulan data persepsi masyarakat responden yang menjawab dari Mahasiswa 33 orang, Swasta 18 orang , pelajar 4 orang. Deskripsi data secara kategori dilakukan menggunakan kategori 3 yaitu "ya, tidak, mungkin". Pengkategorian ini dilakukan dengan bentuk presentase. Hasil penelitian menunjukkan masyarakat yang mendownload lagu di internet adalah 92,7\% dari 55 orang baik legal maupun illegal. Masyarakat yang mengetahui adanya perlindungan lagu oleh UU Hak Cipta adalah $90,9 \%$ dari 55 sampel atau setara dengan 50 orang. Masyarakat belum benar-benar mengetahui apa saja yang termasuk melanggar UU Hak Cipta, Menurut data yang diperoleh hanya 56,4\% sampel yang mengetahui bentuk-bentuk perlanggaran Hak Cipta. Mayarakat yang pernah melanggar hak cipta 18,2 \%, Pengetahuan masyarakat bahwa situs penyedia jasa download lagu melanggar UU Hak Cipta adalah 30,9\%. UU tentang Hak Cipta belum 
terlaksana dengan baik terbukti dari hasil penelitian yang menunjukkan hanya $12,7 \%$ yang merasa bahwa UU sudah terlaksana dengan baik. Regulasi sudah jelas dalam UU Nomor 28 Tahun 2014 tentang Hak Cipta namun dalam pelaksanaan kurang tegas sehingga banyak penyedia lagu di internet yang illegal dan banyak masyarakat yang masih melanggar UU tersebut. Masyarakat yang merasa sudah mendownload lagu di media internet yang legal sebesar $41,8 \%$. Hal ini juga berbanding lurus dengan hasil masyarakat yang mendownload lagu di spotify dan joox yaitu sebesar $41,8 \%$ atau setara dengan 23 orang dari 55 sampel. Persepsi masyarakat tentang individu yang melakukan download lagu tanpa izin adalah hal yang salah karena melanggar UU Hak Cipta dan hal itu sangat merugikan pencipta lagu tersebut. Mendownload lagu gratis di internet berarti sama saja masyarakat tidak menghargai pencipta lagu dan bisa mematikan industri musik. Masyarakat sadar pelanggaran Hak Cipta namun menurut fakta di lapangan masyarakat masih mendownload lagu tanpa izin. Perilaku ini dilakukan karena perlindungan lagu oleh Pemerintah kurang kuat. Belum ada sanksi yang tegas untuk penyedia lagu gratis di internet dan pengunduh lagu gratis di internet. Pemerintah sebagai pondasi utama seharusnya membuat sebuah regulasi yang jelas dan tegas tentang perlindungan hukum hak cipta. Sosialisasi tentang UU Hak Cipta perlu dilakukan karena masyarakat masih minim pengetahuan akan hal itu. Selama masih ada fasilitas download gratis maka akan masih ada pula pengunduh lagu gratis di internet. Analisa kajian yuridis sosiologis terhadap perlindungan lagu-lagu yang di edarkan di masyarakat merupakan kecanggihan teknologi di zaman sekarang. Disinilah menunjukkan bahwa kemajuan teknologi seperti mendorong masyarakat untuk melakukan pelanggaran, bahwa hukum seakan tidak lagi mampu penghalang atau pencegah terjadinya pelaanggaran hak cipta. Apabila dalam prinsip ekonomi masyarakat, bahwa hidup adalah mencari keuntungan besar dengan pengorbanan paling kecil, maka melanggar hak cipta merupakan contoh yang menarik untuk masyarkat. Masyarakat bukan tidak tahu adanya larangan tersebut dan ancaman tersebut. Apabila peraturan baik, sedangkan masyarakat tidak mematuhinya, disini derajat kepatuhan terhadap peraturan perundang-undangan adalah rendah, bila terjadi sebaliknya masyarakat akan terus patuh pada peraturan tersebut.

\section{Simpulan}

Perlindungan Hukum Bagi Pencipta Lagu yang sudah ada dalam Pasal 1 angka 1 Undang-Undang Nomor 28 Tahun 2014 tentang Hak Cipta sudah adanya perlindungan hak 
moral dan hak ekonomi terhadap pencipta lagu atas hasil karyanya. bahwa perlindungan hukum bagi pencipta lagu atau pemegang hak cipta saat ini belum optimal meskipun Indonesia telah memiliki UndangUndang untuk melindungi hak cipta atau karya cipta karena Penegakkan hukum terhadap pelanggaran hak cipta belum dapat dilaksanakan secara maksimal di Indonesia, UU Nomor 28 tahun 2014 tentang Hak Cipta belum terlaksana dengan tegas dan baik, Cara pemblokiran situs yang dianggap melakukan pelanggaran hak cipta atau karya cipta oleh pemerintah tidak mengurangi terjadinya pelanggaran hak cipta yang sering terjadi di media internet, Upaya pemblokiran pun dilakukan apabila ada pengaduan dari pencipta atau pemegang hak cipta, Penghargaan hak cipta di Indonesia masih sangat minim. Pemerintah seharusnya melihat ulang tentang legalitas download lagu melalui media internet, Pembebasan legalitas download di internet harus diimbangi dengan sosialisasi terhadap para pencipta lagu atau pemegang hak cipta lagu tentang pentingnya mendaftarkan ciptaan, maupun terhadap masyarakat tentang budaya menghargai hasil karya orang lain agar penegakkan hukum hak kekayaan intelektual dapat dilaksanakan dengan benar, Pihak Penyedia Jasa Download Lagu tidak memberikan perlindungan hukum sama sekali terhadap pencipta lagu.

Tanggungjawab yang dilakukan oleh penyedia situs download lagu gratis tidak sesuai dengan UndangUndang Hak Cipta dan UndangUndang Informasi dan Transaksi
Elektronik, Penyedia situs illegal memposisikan dirinya sebagai situs pencari lagu yang tidak meng-upload lagu tersebut, Kebebasan informasi dan hak untuk mendapatkan informasi sering dijadikan alasan penyedia jasa download lagu gratis sebagai pembelaan akan pelanggaran Hak Cipta yang dilakukan, berdasarkan Undang-Undang Hak Cipta, maka PJI dapat dianggap turut bertanggung jawab atas pelanggaran Hak Cipta yang dilakukan oleh layanan situs tersebut, karena ketentuan yang ada memberikan peluang untuk menjadikan PJI sebagai turut serta melakukan tindak pidana pelanggaran Hak Cipta maupun dianggap melanggar Hak Cipta sehingga dapat digugat secara perdata untuk mendapatkan ganti kerugian. Kajian sosiologis hukum terhadap tanggung jawab penyedia jasa tersebut masih tidak adanya tanggung jawab kepada pencipta lagu.

Berdasarkan hasil penelitian yang telah dilakukan oleh penulis terkait persepsi masyarakat terhadap perlindungan lagu-lagu yang diedarkan di media internet, maka dapat ditarik kesimpulan bahwa masyarakat belum mengerti tentang UU Hak Cipta sehingga masyarakat masih melakukan pelanggaran.

\section{Saran}

Masyarakat harus sadar untuk menghargai karya cipta orang lain dan harus mampu mengubah budaya menyukai segala sesuatu yang bersifat gratis tetapi illegal sebagai apresiasi penghargaan terhadap hasil karya orang lain yang juga memberikan 
dampak yang baik bagi Negara. Pemerintah sebaiknya mengambil langkah yang serius dalam menangani masalah pelanggaran hak cipta lagu khususnya masalah illegal downloading, mengingat kondisi masyarakat Indonesia yang semakin pintar mengikuti perkembangan kecanggihan teknologi yang ada. Pencipta lagu atau pemegang hak cipta lagu sebaiknya hasil karya atau lagu melakukan pendaftaran atas ciptaannya meskipun pendaftaran dalam hak cipta tidak bersifat wajib, tetapi ini dilakukan demi mencapai keadaan yang kondusif dalam penanganan pelanggaran hak cipta. Pemerintah sudah seharusnya mengatur kebijakan yang lebih mengikuti dan efektif untuk menghentikan pelanggaran hak cipta oleh situs-situs penyedia jasa download lagu gratis, dikarenakan belum adanya tanggungjawab dari situs penyedia jasa download lagu gratis terdebut. Masyarakat juga seharunya mampu mengubah budaya menyukai segala sesuatu yang bersifat gratis tetapi illegal menjadi budaya berbayar murah tetapi legal, sebagai apresiasi penghargaan terhadap hasil karya orang lain yang juga memberikan dampak yang baik bagi Negara. Pemerintah sebaiknya memberikan sosialisasi kepada pencipta lagu dan masyarakat terkait larangan pelanggaran Hak Cipta.

\section{Daftar Pustaka}

Ali, Zunaidin, Sosiologis Hukum, Sinar Grafika, Jakarta, 2016.

Anonim, HAKI dan Implementasinya terhadap Litbang, Investasi \& Inovasi di Indonesia, Jakarta: Departemen Perindustrian, 2007.
BPHN, Seminar Hak Cipta, Binacipta, Bandung, 1976.

Elyta Ras Ginting, Hukum Hak Cipta Indonesia, Bandung: PT. Citra Aditya Bakti, 2012.

Etty Susilowati, Hak Kekayaan Intelektual dan Lisensi Pada HKI, Semarang, Badan Penerbit Undip Press, 2013.

Fairus N.H., Mahir menggunakan Internet, Jakarta: Ganeca Exact, 2005.

H.OK. Saidin, Aspek Hukum Hak Kekayaan Intelektual (Intellectual Property Right), Rajawali Pers, Jakarta, 2010.

Husain Audah, Hak Cipta Dan Karya Cipta Musik, Bogor: PT. Pustaka Litera Antar Nusa, 2004.

Iskandar, Panduan Lengkap Internet, Yogyakarta: Andi Yogyakarta, 2009.

Oksidelfa Yanto Konsep Perlindungan Hak Cipta Dalam Ranah Hukum Hak Kekayaan Intelektual (Studi Kritis Pembajakan Karya Cipta Musik), Yustisia, Jakarta, 2015.

Purnomo Husaini Usman, Metodologi Penelitian Sosial, Jakarta: Bumi Aksara, 1995.

Ramli, Ahmad M., E-Tutorial HKI, Jakarta, 2014.

Ranti Fauza Mayana, Perlindungan Desain Industri Di Indonesia Dalam Era Perdagangan Bebas, Jakarta: Grasindo,2004.

Ronny Hanitijo Soemitro, Metode Penelitian Hukum dan Jurimetri, Ghalia Indonesia, Jakarta, 1995.

Siti Ruhani, Susi eja Y., Kekerasan Terhadap Perempuan di Ruang 
Publik, Yogyakarta: Pusakas UGM, 2002.

Soerjono Soekanto, Pengantar

Penelitian Hukum, Jakarta: UIPress, 1996.
Tomi Suryo Utomo, Hak Kekaayaan Intelektual di Era Global, Yogyakarta: Graha Ilmu, 2010.

Yusran Israini, Buku Pintar HAKI:

Tanya Jawab Seputar Hak Kekayaan Intelektual, Bogor: Ghalia Indonesia, 2010. 